Bangladesh J. Bot. 42(2): 223-229, 2013 (December)

\title{
LIMNOLOGY OF LAKE RAINKHYONGKAIN OF BANGLADESH WITH A NEW RECORD OF MARCHANTIA POLYMORPHA L. VAR. AQUATICA NEES
}

\author{
Md Almujaddade Alfasane, Md Sharif Ullah and Moniruzzaman KhondKeR* \\ Department of Botany, University of Dhaka, Dhaka 1000, Bangladesh
}

Key words: Rainkhyongkain, Limnology, Marchantia polymorpha var. aquatica Nees, Phytoplankton, Bangladesh

\begin{abstract}
In lake Rainkhyongkain, water temperature, $\mathrm{pH}$, conductivity and total dissolved solids (TDS) were recorded $33.5^{\circ} \mathrm{C}, 7.39,308 \mu \mathrm{S} / \mathrm{cm}$ and $49 \mathrm{mg} / 1$, respectively. The mean values $(n=4)$ of dissolved oxygen content (DO), alkalinity, soluble reactive phosphorus (SRP), soluble reactive silicate (SRS) and $\mathrm{NO}_{3}-\mathrm{N}$ were $7.93 \pm 0.78 \mathrm{mg} / 1,1.70 \pm 0.12 \mathrm{meq} / 1,17.25 \pm 0.62 \mu \mathrm{g} / 1,10.44 \pm 0.72 \mathrm{mg} / 1$ and $34.00 \pm 4.00 \mu \mathrm{g} / \mathrm{l}$, respectively. The phytoplankton biomass as chlorophyll $a(\mathrm{chl} a)$ was found very low $(4.93 \pm 0.51 \mu \mathrm{g} / \mathrm{l})$ with a phaeopigment concentration of $1.97 \pm 0.51 \mu \mathrm{g} / \mathrm{l}$. A total of 16 phytoplankton taxa were recorded of which Cyclotella comensis (V. Keissler) Lemm. was dominant followed by Protoperidinium conicum (Gran) Balech, Coelosphaerium kuetzingianum Näg., Euglena spp. and Mallomonas paxillata Bardley. For the first time in Bangladesh Marchantia polymorpha L. var. aquatica Nees was found to grow in masses in the shallow littoral of the lake. Among the dominant macrophytes of the littoral, Nymphaea stellata Willd., Nymphoides indicum (L.) O. Kuntze and Monochoria hastata (L.) Solms were common.
\end{abstract}

\section{Introduction}

Preliminary limnological information on two of the three natural lakes of Bangladesh, namely Lake Bogakain and Lake Ashura are now available (Khondker et al. 2010, Alfasane et al. 2010, 2012). The third lake, Lake Rainkhyongkain though investigated phycologically by Islam (1969) lacking limnological information. However, it has been regarded as a treasure of aquatic biodiversity (Husain 1967, Islam 1969). Thus, the present research work was undertaken to study the limnological features of the lake.

\section{Materials and Methods}

Geographically, Lake Rainkhyongkain is situated in the Bilaicchari Upazila, district Bandarban, Bangladesh in $22^{\circ} 01^{\prime} 10.74^{\prime \prime} \mathrm{N}$ and $92^{\circ} 32^{\prime} 36.68^{\prime \prime} \mathrm{E}$ and is bounded in the east by the Mizoram state of India and in part by the Chin State of Myanmar. Other features of the lake have been described in Husain (1967) and Islam (1969). The lake is more than one kilometer long and 200 - $300 \mathrm{~m}$ wide. It is situated at an altitude of $359 \mathrm{~m}$ above sea level (Roy, http://chakmaraj. com/about-chakma-raj/5articles/38-reingkhyongkine-lake-tour-chittagong-hill-tracts-22-28-dec-2011). The highest depth of the lake is known to be $82.30 \mathrm{~m}$.

Surface water temperature (Traceable water proof digital thermometer, CONTROL Co., USA), pH (Griffin, UK), conductivity (HANNA Instruments HI 9033, 9044, Singapore) of the lake and TDS (HANNA Instruments HI 9033, 9044, Singapore) were measured in situ by using respective field meters. Phytoplankton sample was collected at a depth of $30 \mathrm{~cm}$ by dipping a plastic container. The sample was then poured in a one liter capacity plastic made screw capped bottle preoccupied with $1 \mathrm{ml}$ Lugol's iodine solution for sedimentation. Four borosilicate BOD bottles (Pyrex, U.K.; $125 \mathrm{ml}$ capacity) were filled in the site and fixed for dissolved oxygen (DO) determination by Winkler's method (Wetzel and Likens 2000). Another screw capped plastic made dark container of five liter capacity was also dipped to same depth and filled with lake water

*Author for correspondence: <mkhondker@yahoo.com>. 
of pelagic region. This water sample was carried to the laboratory in a Cool Box and used for determining alkalinity, soluble reactive phosphorus (SRP), soluble reactive silica (SRS), nitratenitrogen, chl $a$ and phaeopigment concentrations (Mackereth et al. 1978, Murphy and Riley 1962, Wetzel and Likens 2000, Müller and Wiedemann 1955, Marker et al. 1980). Littoral macrophytes were collected manually and kept in either one liter capacity wide mouthed screw capped plastic made specimen jars and/or in transparent polythene bags.

The qualitative analysis of phytoplankton was carried out with the help of Siddiqui et al. (2007a) and Ahmed et al. $(2008,2009)$ whilst, the macrophytes were identified after Khan and Halim (1987), Subramanyam (1962) and Fassett (1957). The liverwort specimen was identified following Siddiqui et al. (2007b) and Kürschner and Frey (2011). The phytoplankton population were quantified using a Hawksley microplankton counting chamber with improved Neubauer Rulling (Hawksley Ltd., Lancing, England) under a Nikon compound microscope (Japan) at a magnification of $400 \times$.

\section{Results and Discussion}

At the time of sampling, the pelagic water looked slightly turbid but the water in the littoral, particularly at a depth where the sheet of Marchantia were submerged looked reddish. It is known that the color of the lake water always takes a course of changes from dark grey, reddish to creamish hue annually. For this reason and out of fear nobody drinks the water of the lake (Roy, $2011 \mathrm{http}: / /$ chakmaraj.com/about-chakma-raj/5articles/38-reingkhyongkine-lake-tour-chittagonghill-tracts-22-28-dec-2011). During the present visit the water temperature was recorded $33.5^{\circ} \mathrm{C}$, $\mathrm{pH} 7.39$, conductivity $308 \mu \mathrm{S} / \mathrm{cm}$ and TDS $49 \mathrm{mg} / \mathrm{l}$. DO, alkalinity, SRP, SRS and $\mathrm{NO}_{3}-\mathrm{N}$ were $7.93 \pm 0.78 \mathrm{mg} / \mathrm{l}, 1.70 \pm 0.12 \mathrm{meq} / \mathrm{l}, 17.25 \pm 0.62 \mu \mathrm{g} / \mathrm{l}, 10.44 \pm 0.72 \mathrm{mg} / \mathrm{l}$ and $34.00 \pm 4.00 \mu \mathrm{g} / \mathrm{l}$, respectively. In Lake Rainkhyongkain, conductivity, TDS, alkalinity, silicate and nitrate nitrogen concentration were found relatively higher compared to lake Bogakain (Khondker et al. 2010). Both the lakes are situated to an almost similar altitude but the catchment characteristics are rather different. Except one side, Lake Rainkhyongkain has a peaty shore which is absent in Lake Bogakain and due this reason the former lake contains high values of conductivity, TDS, alkalinity and silicate concentration. Because of this peaty nature of the shore of Lake Rainkhyongkain, Marchantia polymorpha L. var. aquatica Nees colonized. Husain et al. (1967) also reported similar nature of Lake Rainkhyongkain.

From the lake, a total of 16 phytoplankton species were recorded of which the most dominant algal Division was Chrysophyta where a total of six taxa were recorded (Table 1). The division Chlorphyta and Euglenophyta were represented by three taxa in each. Cyanophyta was represented by two taxa, whilst Pyrrhophyta and Cryptophyta were represented by one taxon in each (Table 1). In lake Bogakain a total of 40 phytoplankton taxa were reported and was found to be dominated by the members of the Division Chlorophyta. Silicate concentration $(10.44 \pm 0.72 \mathrm{mg} / \mathrm{l})$ of Lake Rainkhyongkain might be a factor of phytoplankton dominance by chrysophytes. On the other hand, very poor silicate concentration $(0.16-0.62 \mathrm{mg} / \mathrm{l})$ was reported from Lake Bogakain (Khondker et al. 2010). Chl $a$ concentration and phaeopigment concentration from the pelagic water were recorded $4.93 \pm 0.51$ and $1.97 \pm 0.51 \mu \mathrm{g} / 1$ which is similar to the surface concentration of Lake Bogakain (Khondker et al. 2010).

In Lake Rainkhyongkain, the phytoplankton population was dominated by Cyclotella comensis followed by Protoperidinium conicum, Coelosphaerium kuetzingianum, Euglena spp. and Mallomonas paxillata. Of these, Cy. comensis was found common with lake Bogakain (Khondker et al. 2010). Islam (1969) reported only some submerged and attached algae from Lake Rainkhyongkain. 
Table 1. Density of phytoplankton of the Lake Rainkhyongkain.

\begin{tabular}{llc}
\hline Division & Taxa & Density $( \pm \mathrm{sd}) \times 10^{6} / 1$ \\
\hline Cyanophyta & Chroococcus dispersus (V. Keissler) Lemm. & $2.90 \pm 5.85$ \\
& Coelosphaerium kuetzingianum Näg. & $6.30 \pm 5.32$ \\
Chlorophyta & Crucigenia truncata G.M. Smith & $0.66 \pm 2.30$ \\
& Scenedesmus quadricauda (Turp.) de Brébisson & $0.99 \pm 2.87$ \\
& Tetraedron trigonum (Nägeli) Hansgirg & $0.33 \pm 0.81$ \\
Euglenophyta & Euglena spp. & $5.60 \pm 9.60$ \\
& Lepocinclis salina Fritsch & $0.33 \pm 1.15$ \\
& Trachelomonas raciborskii Wolosz. & $0.66 \pm 2.00$ \\
Chrysophyta & Cyclotella comensis Grunow & $33.50 \pm 44.69$ \\
& Cymbella tumida (Breb. Ex Kütz) Van Heurek & $00.33 \pm 0.81$ \\
& Navicula placentula (Her.) Grun. & $2.9 \pm 2.87$ \\
& Nitzschia fruticosa Hust. & $0.99 \pm 0.82$ \\
& Synedra ulna (Nitzsch) Ehr. & $0.33 \pm 1.15$ \\
Pyrrhophyta & Mallomonas paxillata Bardley & $5.30 \pm 7.58$ \\
Cryptophyta & Protoperidinium conicum (Gran) Balech & $9.29 \pm 15.52$ \\
\hline
\end{tabular}
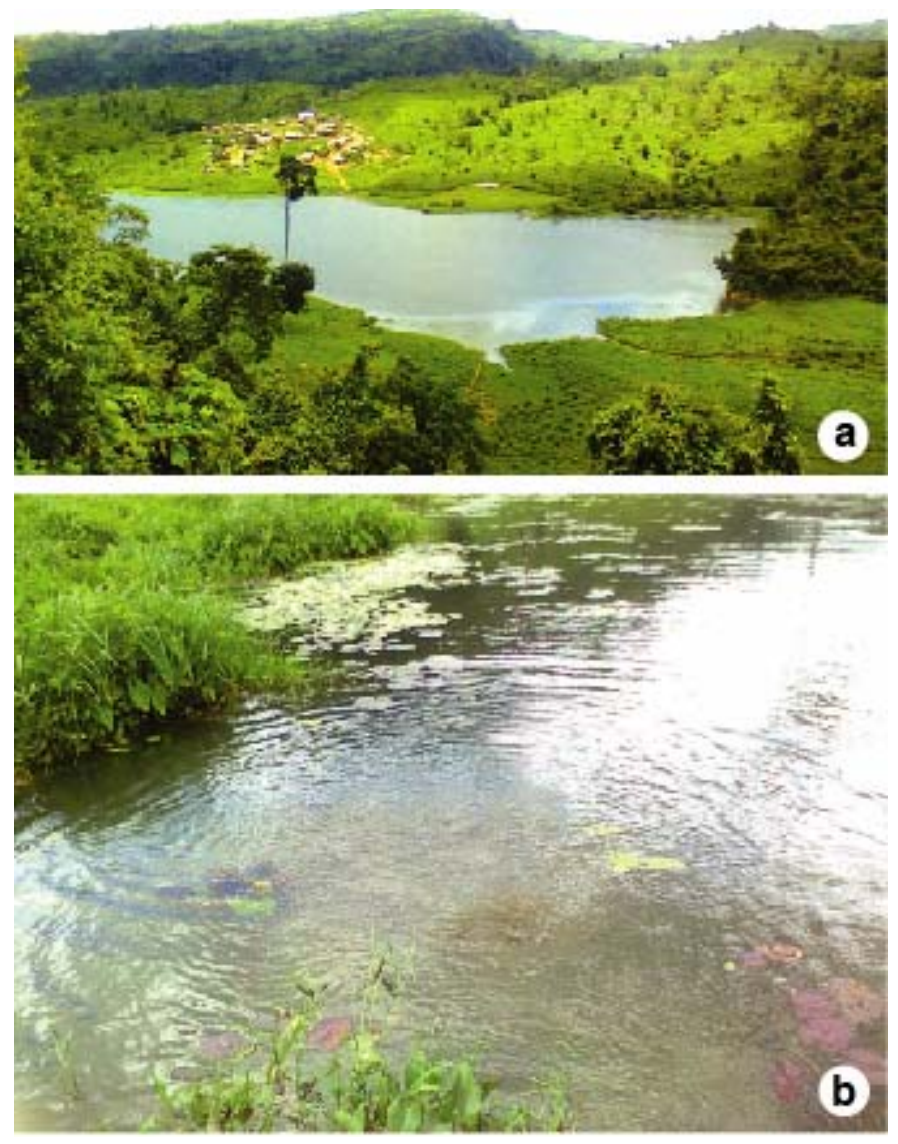

Fig. 1. Lake Rainkhyongkain and its littoral. (a). Lake overview; (b). Littoral macrophytes dominated by Nymphoides indicum. 

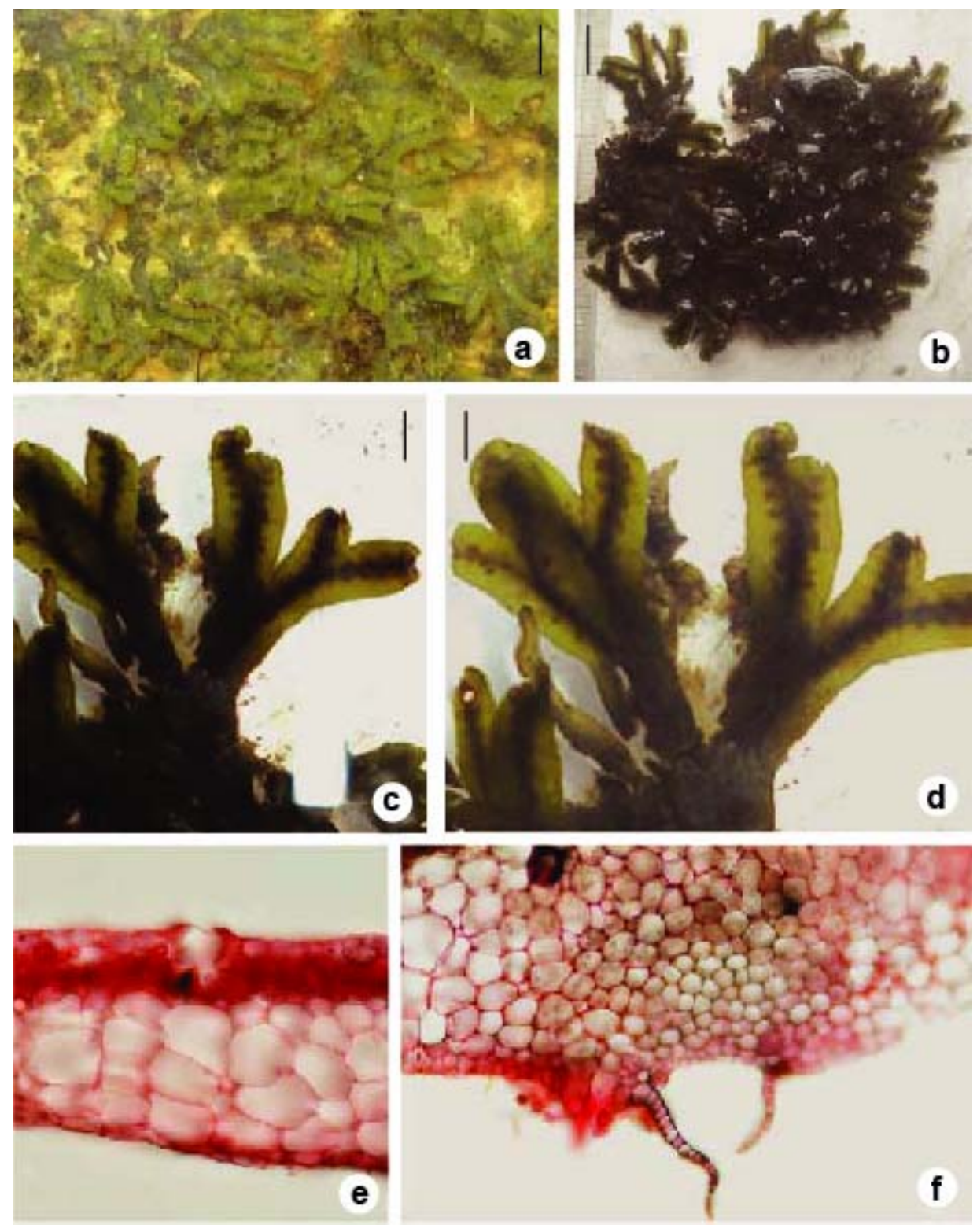

Fig. 2. Marchantia polymorpha var. aquatica. (a), Thalli under water; (b), Masses of fronds; (c), Ventral surface of the thallus; (d), Dorsal surface of the thallus; (e), T.S. of the thallus showing air pore $\times 200$; (f), T.S of the thallus showing scales $\times 200$ (safranine dyed) Scale $=2.0 \mathrm{~cm}$.

The lake littoral was dominated by Nymphaea stellata Willd., Nymphoides indicum (L.) O. Kuntze and Monochoria hastata (L.) Solms (Fig. 1). The vast peaty shoreline was mostly dominated by Colocasia sp. and grasses. Sample of one liverwort species was collected from a depth of $\sim 0.50 \mathrm{~m}$ near the shore of the Lake Rainkhyongkain. It was identified as Marchantia polymorpha L. var. aquatica Nees and hitherto is the first report of its kind in Bangladesh (Fig. 2). 
In Bangladesh, so far two species of Marchantia L. have been reported from the terrestrial habitats. These are M. nepalensis L. and M. palmatia Nees (Siddique et al. 2007b). Among aquatic Hepaticae, eight hygrophilous species are reported of which Marchantia aquatica (subsp. polymorpha) was one of them (Hutchinson 1975). Most of these Hepaticae when grow under water remain sexually sterile and show morphological changes from the typical marshy and sub-aerial habitats. Though M. aquatica was believed to be distinct from M. polymorpha (Hutchinson 1975), presently it is considered as M. polymorpha (Kürschner and Frey 2011, Anonymous http://www.uniprot.org/taxonomy/3197). However, Matthews (1993) discussed that for common liverworts, the currently accepted scientific name is Marchantia polymorpha L. but having three varieties determined on the basis of ecological and morphological characteristics. These are M. polymorpha L. var. polymorpha, M. polymorpha L. var. aquatica Nees (growing submerged with erect or sub-erect thalli). The third one is M. polymorpha var. alpestris Nees (growing mostly in the alpine regions as dense compact masses). The morphological and ecological description of M. polymorpha var. aquatica as provided by Matthews (1993) fits well with the present specimen. Therefore, the present specimen has been identified as Marchantia polymorpha L. var. aquatica Nees.

\section{Class Hepaticopsida, Order Marchantiales, Family Marchantiaceae Genus Marchantia L.}

Marchantia polymorpha L. var. aquatica Nees

(Fig. 2)

(Hutchinson 1975, p. 46, Figs 19G-F; Matthews 1993)

Thallus light green, dichotomously branched, erect or sub-erect, $2.0-2.5 \mathrm{~cm}$ long, $0.5-0.8$ $\mathrm{cm}$ broad differentiated into upper photosynthetic and lower storage region, prostrate, margin lobulate, ventral multicellular scales present, hyaline, mid rib dark, prominent, air pore and branched photosynthetic filaments are present in the upper photosynthetic region.

Notes: Since the thallus masses grew underwater, it was sexually sterile. From the genus Marchantia, M. polymorpha var. aquatica is the only taxon which grows under water and therefore, by considering the ecological, morphological and anatomical features the specimen has been identified.

Regarding the aquatic flora of the Lake Rainkhyongkain, Islam (1969) is the only known source. In his contribution, Chara corallina var. corallina (A. Br.) Wood was reported as submerged macro-algae while Cladophora lehmanniana?, Lyngbya bergei Smith, L. majuscula Harvey ex Gomont, L. sordea (Ganard) Gomont and Scytonema tolypothrichoides Kutz. were reported as attached form. In the present investigation occurrence of some larger macrophytes namely, N. stellata, Nymphoides indicum and M. hastata has been confirmed. Besides, floristic composition of pelagic phytoplankton has also been revealed. Husain (1967) characterized the lake as peaty and acidic but Islam (1969) by observing the indicator species, opined that it is alkaline and eutrophic drainage type. But none of them had any data on chemical water quality. In the present investigation, few water quality data has been furnished based on the collection of a single water sample. The $\mathrm{pH}$ recorded is little above neutrality (7.31) which does not support a peaty nature of water but the presence of submerged mats of Marchantia polymorpha var. aquatica, changing water color, relatively high conductivity and TDS and low SRP and chl $a$ concentration supports a peaty nature of water. M. polymorpha var. aquatica colonizes in peaty water (Matthews 1993). Islam (1969) mentioned that at least one part of the shore of the lake is steep and devoid of littoral vegetation. In the present investigation a vast majority of the shoreline was seen to be covered by Pteris sp. and Colocasia sp. accompanied by some grasses. Lake Rainkhyongkain is a drainage lake (Islam 1969, Roy, $2011 \mathrm{http} / /$ chakmaraj.com/about-chakma- 
raj/5articles/38-reingkhyongkine-lake-tour-chittagong-hill-tracts-22-28-dec-2011) but whether it is passing eutrophic or dystrophic stage is difficult to comment. However, the occurrence of Marchantia polymorpha var. aquatica population in the littoral, low concentrations of chl $a$ and SRP and poor phytoplankton density suggests a peaty low productive nature of the lake.

\section{Acknowledgements}

The present research work was carried out under a project entitled 'Limnological study of some unexplored natural lakes of Bangladesh' financed by the University Grants Commission (UGC), Bangladesh which is duly acknowledged gratefully.

\section{References}

Ahmed ZU, Begum ZNT, Hassan MA, Khondker M, Kabir SMH, Ahmad M, Ahmed ATA, Rahman AKA and Haque EU (Eds) 2008. Encyclopedia of flora and fauna of Bangladesh. Vol. 3, Algae, Chlorophyta (Aphanochaete-Zygnemataceae). Asiatic Soc. Bangladesh, Dhaka. pp. 812.

Ahmed ZU, Khondker M, Begum ZNT, Hassan MA, Kabir SMH, Ahmad M, Ahmed ATA and Rahman AKA (eds) 2009. Encyclopedia of flora and fauna of Bangladesh. Vol. 4, Algae, Charophyta Rhodophyta (Achnanthaceae-Vaucheriaceae). Asiatic Soc. Bangladesh, Dhaka. pp. 543.

Alfasane MA, Gani MA, Islam MS and Khondker M 2012. Limnology of lake Ashura, Dinajpur, Bangladesh. Bangladesh J. Bot. 41(1): 43-48.

Alfasane MA, Khondker M, Islam MS and Bhuiyan MAH 2010. Egeria densa Planchón (Hydrocharitaceae): A new angiospermic record for Bangaldesh. J. Plant Taxon. 17(2): 209-213.

Fassett NC 1957. A manual of aquatic plants. Univ. Wisconsin Press, Madison. pp. 405.

Husain KZ 1967. Expedition to Chittagong Hill Tracts (Bandarban Sub-Division, 1965). J. Asiat. Soc. Pak. 12(1): 122-165.

Hutchinson GE 1975. A treatise on limnology. Vol. III. Limnological Botany. John Wiley and Sons, New York. pp. 660.

Islam AKMN 1969. A preliminary report on the phytoplankton and other algae of Chittagong Hill-Tracts. J. Asiat. Soc. Pak. 14(3): 353-363.

Khan MS and Halim M 1987. Aquatic angiosperms of Bangladesh. Bangladesh Nat. Herbarium, BARC, Dhaka. pp. 120.

Khondker M, Alfasane MA, Islam MS, Bhuiyan MAH and Gani MA 2010. Limnology of lake Bogakain, Bandarban, Bangladesh. Bangladesh J. Bot. 39(2): 153-159.

Kürschner H and Frey W 2011. Liverworts, mosses and hornworts of Southwest Asia Marchantiophyta, Bryophyta, Anthocerotophyta. Nova Hedwigia 139: 1-240.

Mackereth FJH, Heron J and Talling JF 1978. Water analysis: some revised methods for limnologists. Freshwater Biol. Assoc. Pub. No. 36, pp. 120.

Marker AFH, Nusch EA, Rai H and Riemann B 1980. The measurement of photosynthetic pigments in freshwaters and standardization of methods: conclusions and recommendations. Archiv für Hydrobiologiie Ergebnisse der Limnologie 14: 91-106.

Matthews RF 1993. Marchantia polymorpha. In: Fire Effects Information System, [Online]. U.S. Department of Agriculture, Forest Service, Rocky Mountain Research Station, Fire Sciences Laboratory (Producer. Available: http://www.fs.fed.us/database/feis/ [2013, September 28].

Müller R and Wiedemann F 1955. Die Bestimmung des Nitrats in Wasser. Jahrb. Wasserchem. Wasserreinigungstechnik. Verlag Chimie 12: 247-271.

Murphy J and Riley JP 1962. A modified single solution method for the determination of phosphate in natural waters. Anal. Chim. Acta 27: 31-36.

Roy RD 2011 http://chakmaraj.com/about-chakma-raj/5articles/38-reingkhyongkine-lake-tour-chittagonghill-tracts-22-28-dec-2011. 
Siddiqui KU, Islam MA, Ahmed ZU, Begum ZNT, Hassan MA, Khondker M, Rahman MM, Kabir SMH, Ahmad M, Ahmed ATA, Rahman AKA and Haque EU (eds) 2007a. Encyclopedia of flora and fauna of Bangladesh. Vol. 2, Cyanobacteria, Bacteria and Fungi. Asiatic Soc. Bangladesh. pp. 415.

Siddiqui KU, Islam MA, Ahmed ZU, Begum ZNT, Hassan MA, Khondker M, Rahman MM, Kabir SMH, Ahmad M, Ahmed ATA, Rahman AKA and Haque EU (eds) 2007b. Encyclopedia of flora and fauna of Bangladesh. Vol. 5, Bryophytes, Pteridophytes, Gymnosperms. Asiatic Soc. Bangladesh. pp. 391.

Subramanyam K 1962. Aquatic angiosperms. Botanical Monogr. No. 3. Council of Scientific \& Industrial Research, New Delhi. pp. 190.

Wetzel RG and Likens GE 2000. Limnological analysis ( $3^{\text {rd }}$ Edn). Springer, New York. pp. 429.

(Manuscript received on 11 September, 2013; revised on 1 October, 2013) 